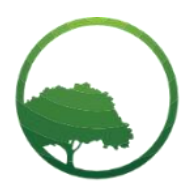

Research in Business \& Social Science

\title{
Managerial intellectual capital on the internationalization of commercial banks in Kenya
}

\author{
Philip Omondi Peters@(a), Timothy Chrispinus Okech@(b) \\ (a,b) United States International University-Africa, Kenya
}

Crossref

\section{A R T ICLE INFO \\ Article history: \\ Received 04 April 20 \\ Received in revised form 21 April 20 \\ Accepted 26 April 20}

Keywords:

Managerial, Global mindset,

Intellectual Capital,

Internationalization

JEL Classification:

M1

\begin{abstract}
A B S T R A C T
Managerial intellectual capital is one of the attributes of a global mindset, associated with knowledge, skill level, and creation of an organization competitive advantage. This paper sought to delve into the concept of internationalization of commercial banks by examining the relationship between managerial intellectual capital and internationalization of commercial banks in Kenya. The paper used positivism philosophical approach and adopted cross-sectional descriptive research design. The target population was top and middle level managers in commercial banks in Kenya. Data was collected using a structured questionnaire and analyzed using Statistical Package for Social Sciences (SPSS) version 22.0 to obtain both descriptive and inferential statistics. In addition, Structural Equation Modelling (SEM) was used to establish the influence of managerial global mindset attributes on internationalization of commercial banks in Kenya. The study established that there was a significant and positive relationship between human capital, relational capital and structural capital as attributes of managerial intellectual capital and internationalization of commercial banks in Kenya. Further, the study established that human capital, relational capital, and structural capital have significant influence on the success of internationalization strategy of commercial banks in Kenya. Thus, structural capital, human capital and relational capital, which are the managerial intellectual capital attributes, jointly influence the success of internationalization of commercial banks in Kenya. It is therefore recommended that when appointing managers, the management of commercial banks should consider factors such as an individual's knowledge on global industry, global value networks, and global organization.
\end{abstract}

(C) 2020 by the authors. Licensee SSBFNET, Istanbul, Turkey. This article is an open access article distributed under the terms and conditions of the Creative Commons Attribution (CC BY) license (http://creativecommons.org/licenses/by/4.0/).

\section{Introduction}

Global Mindset entails the ability to absorb information, traditions, and cultural norms from around the world and be able to conceptualize how to make an impact in all environments. This has three key elements namely intellectual capital, psychological capital, and social capital (Maike \& Franziska, 2017). Whereas there are three elements of global mindset, in this study, the focus is intellectual capital. Intellectual capital entails the managers' cognitive and intellectual capabilities (Crowne, 2013). Managers with a global intellectual mindset are capable of conducting business globally and conceive international strategies due to their understanding of global markets and world economic trends (Fatehi \& Ghadar, 2014). Firms not only need to develop individual global mindsets at the management level, but also develop networks and connections to influence these mindsets at the organizational level (Bartlet \& Beamish, 2014). For instance, an organization with intellectual mindset benefits by acquiring competitive advantages (House, 2013).

Five factors define intellectual capital. These include knowledge of global industry which encompasses global business trends and competition, economic, political and institutional systems, and global transactions. Knowledge of global value networks incorporate proper understanding of the global supply chains, the importance and the process of building global value networks, and the importance of global strategic alliances. Knowledge of the global organization comprises of the understanding of tension between global efficiency and local effectiveness, global implications when making global decisions, and the importance of global inclusive

* Corresponding author. ORCID ID: 0000-0001-5213-7269

(C) 2020 by the authors. Hosting by SSBFNET. Peer review under responsibility of Center for Strategic Studies in Business and Finance. https://doi.org/10.20525/ijrbs.v9i3.695 
visions and finding common views. Four, intellectual capital is cognitive complexity that is characterized by the ability to define and challenge opportunities from multiple and diverse perspectives, find solutions to challenges and opportunities, and to bridge and integrate among multiple perspectives. Finally, cultural acumen feature encompasses cultural self-awareness, understanding cultural similarities and differences, and knowledge of other histories and cultures (Marthinsen, 2015).

The recent wave of bank internationalization is characterized by not only the financial institutions' existing relationships, but also by global banks' increased search for opportunities to widen their activities in the financial markets in the host-country, mainly through; controlling stakes, acquisition of the majority or minority, and non-controlling stakes (Yamada, 2016). Accordingly, through the current strategy of going global, universal banks targets diversification of banking activities into some domestic financial markets through a network of branches and greater integration into the local market (Mori, 2015). In the past, multinational bank strategies were mainly geared towards serving banks' corporate customers and give support to domestic firms to access the international financial market (Abd, Hassan, \& Ahmad, 2014).

Currently, such strategies have been stimulated by the gradual flexibility of legal restrictions concerning the presence of multinational banks in local markets, in both developed and developing nations (Jie, 2014). Regionally, commercial banks show three different internalization patterns, namely; gradual, rapid, and rapid but late patterns (Story, Barbuto, Luthans \& Bavarid, 2014). This means that many commercial banks that intend to internationalize have a strong experience in the domestic market, whereby they encounter a strong competition from domestic and multinational banks. Some banks have a strong growth potential in their domestic market, which makes them embark on the internationalization process (Mona, 2017).

Currently, Kenya has forty commercial banks and one mortgage financial institution, out of which twenty-six are locally owned while fourteen are foreign owned. Out of the twenty-six that are locally owned, only eight have set up branches in the regional markets. The strategy of expanding the branch network, both within Kenya and in the greater East African region, automation of service needs, and globalization challenges has enhanced the growth (Chebii, 2015). The Kenyan banking sectors' continued expansion into the East African region may foster its growth momentum (Asira, 2013). Likewise, the sector is expected to play a pivotal role in financing initiatives that could propel Kenya into a middle-income country as envisaged in the Vision 2030 (Gacoki, 2014). The advancement in communication technology, the realization of the East African community (EAC), improved infrastructure in East Africa, and overall globalization can also be attributed to the changing banking industry (Conrad \& Meyer, 2018). Advancement in communication technology has made it easy to connect regional offices and facilitated timely sharing of decision-making information.

The focus of the study was that though there is a global wave of internationalization of commercial banks, it remains unclear whether intellectual capital, as an attribute of a managerial global mindset, can leverage commercial banks in Kenya to internationalize the operations. Previous studies on global mindset and internationalization majorly focused on global mindset and internationalization among small and medium enterprises (Gota, 2017; Islam \& Van Zijil, 2016). Additionally, majority of these studies were done in other countries and none of them focused on the Kenya context (Hugo, 2016; Mona, 2017). This gives evidence of contextual knowledge gap on the influence of managerial global mindset on internationalization of commercial banks, especially in the Kenyan context. Consequently, the current study fills the existing contextual gaps and research gaps on the influence of managerial intellectual capital on the internationalization of commercial banks in the Kenyan context.

\section{Literature review}

\section{Theoretical background}

\section{The Uppsala model}

The theoretical foundation of this paper is based on the Uppsala Model of internationalization processes as proposed by Johanson and Vahlne in1977. The model posits that the internationalization process is evolutionary and sequential and it develops, as a firm becomes continuously involved on the international market. This makes internationalization a gradual process (Johanson \& Vahlne, 2017). The firm goes into one country at a time depending on the knowledge and information gathered about the destination market. A firm starts by gaining knowledge and experience about their internal market, then at some point turn into external markets (Levene, 2015). The attractiveness of the external markets varies depending on the geographical and cultural proximity to the home country (Conrad \& Meyer, 2018). Therefore, firms first access external markets in countries that are geographically close to their home country, and then later on extend access to external markets in countries that are far from home countries (Massingham, 2013).

The Uppsala model relates to a firm's growth opportunities and economic logic, taking into consideration the managerial behavior of learning and commitment (Marta, 2015). These are assumptions that gain validity in today's globalized economy, given that there is high technology and highly networked economies. Internationalization of firms has become a lot easier due to a more open world when crossing frontiers, through developing new information means and better and more reliable infrastructure around the globe (Langley et al, 2015). Technology has also allowed a more dispersed structure for firms, whereby outsourcing and vertical disintegration of large firms, in many cases, is an actuality today (Conrad \& Meyer, 2018). Thus, the Uppsala model has been dealing with national borders as real and existing, yet in reality they have become more invisible. 
The criticism of Uppsala Model of internationalization is that it was mainly based on empirical findings of the internationalization process of large Swedish Industrial firms (Johanson \& Vahlne, 2017). This raises the concern on whether the model can be applied to the financial sector. In addition, since the invention of the original Uppsala Model, the business setting has changed and the service sector has out grown the production sector and new technologies have extremely influenced the day-to-day business (Johanson \& Vahlne, 2017). The model has been tried and tested mainly in manufacturing industries, from where the concept originated. However, considering the growing importance of services in the world economy, it is questionable whether the model assumptions would also apply to service industry, such as in commercial banking.

However, a survey conducted by Boddewyn et al. (1986)) showed that internationalization approaches developed to explain manufacturing firms' foreign expansion might also apply to service industries very well. The Uppsala Model on Internationalization by Johanson and Vahlne (2017) forms a basis for this paper as it explains the process through which commercial banks enter global markets and their motivation for doing so. The model also anchors intellectual capital as an attribute of global mindset.

\section{Empirical studies}

Various scholars have related intellectual capital and internationalization of commercial banks. For example, Vatamanescu et al. (2019) conducted a study on the internationalization of small and medium-sized enterprises, focusing on sustainable competitive advantage in Turkey. The study aimed at bridging three major concepts; intellectual capital (IC), the internationalization process, and the sustainable competitive advantage of small and medium-sized enterprises. The research design used comprised of literature review of peer-reviewed journal articles through stepwise approach and multifold criteria. In this case, over 100 peer-reviewed journal articles were critically scrutinized. Results established that few empirical studies have been undertaken connecting intellectual capital (IC), the internationalization process, and the sustainable competitive advantage of small and medium-sized enterprises. Further, the results showed that there are more quantitative oriented studies focusing on this area than the qualitative oriented ones. The study concluded that there is necessity for further studies focusing on the interaction of intellectual capital (IC), the internationalization process, and the sustainable competitive advantage of small and medium-sized enterprises

Another study was carried to measure intellectual capital and internationalization among Malaysian Banks (Poh, Kilicman, \& Ibrahim, 2018). The study findings indicated that banks in the Malaysia did not emphasize more on innovation and global orientation as they do to product differentiation, cost minimization, and market niche to compete in the market place. The findings also showed that banks in Malaysia were less inclined to making investment in internet, and research and development (R\&D). This reflects badly on their effectiveness. The study indicated that investment in R\&D for banks require more skilled experts who can provide the much desirable knowledge and innovation for organizations' sustainability in the international markets.

Similarly, Ariff, Islam and Van Zijil (2016) conducted a study on the relationship between intellectual capital and financial performance of companies listed in the U.S.A stock exchange. VAIC method was used to measure intellectual capital, while the indicators of financial performance that were used included; earnings per share, equity and annual return per share. The results of the study revealed that there is a positive correlation between intellectual capital and expected performance of companies listed in the U.S.A stock exchange. In addition, the growth rate of intellectual capital has a positive relationship on firm performance.

A longitudinal study conducted by Singh, Sidhu and Joshi (2016) examined how intellectual capital, human capital, organizational capital and social capital influenced various innovative capabilities (incremental and radical) among Indian Banks. This study compared public and private sector banks. The findings indicated that selective inter-relationships among organizational capital, human capital, and social capital influenced radical and incremental innovative capabilities. Further, the findings showed that there exists a mutually positive correlation between innovative activities and intellectual capital, and that the amassing of intellectual capital of banks has positive influence on their development and expansion. This means that the more the intellectual capital, the more the added value contributed and the higher the chances for expansion.

A study by Nadeem (2016) on the effect of current-period intellectual capital disclosure on earnings and current annual stock return during a civil-war period found that firms hardly include the current period intellectual capital disclosure in the current stock return and the increase of the same has no influence on earnings included in the current stock return. However, the study noted that future accounting-based earnings by contrast are incorporated in the current stock return. These findings provide insights into the intellectual capital disclosure practice and its influence on stock return. Similarly, Otor (2015) examined the influence of intellectual capital on the performance of small and medium enterprises (SMEs) in Mombasa County, Kenya. The study employed descriptive research design. From the findings, it was clear that a management's technical skills greatly influenced the performance of the SMEs, followed by managerial experience. Further, the findings showed that the motivation for entrepreneurship influenced the growth of the SMEs, the same way the SMEs risk taking propensity among all the entrepreneurial skills factors does.

Research by Abd, Hassan and Ahmad (2014) on the relationship between intellectual capital, innovation and organizational performance among Malaysian commercial banks showed that human capital contributes more to innovation and organizational performance compared to structural and relational capital. Accordingly, each part of intellectual capital's coefficient of efficiency has significant and positive impact on the rate of return of investment. This means that the higher the intellectual capital the companies have, the better their financial performance. Furthermore, the findings showed that physical and human capital also create value for the firms. 
In the study on the impact of human capital efficiency on the financial and market performance of South African listed companies, Morris (2014) found that one of the major obstacles for African SMEs to internationalize their business is the weak management skills based on knowledge of international finance, communication, time, and assistance. Such expertise activity is crucial for firms since they continuously need to explore new opportunities to respond to increasingly indefinite and changing market demands. However, the extent of overseas' market hostility can also moderate the success of international entrepreneurship, even in the presence of bidirectional moderating relationship between firms' international entrepreneurial orientation and internationalization processes. Different types of network ties at home country can moderate the impact of entrepreneurship on enterprises' international activities.

Thi (2014) conducted a study on the internationalization process of all companies of the Vietnamese exchange for the period 2001 to 2005. The study examined the relationship between the efficiency of the Intellectual Capital (IC) of these companies and its human and structural components using market valuation, return on assets, and return on equity and productivity as measures of companies' performance. The results of the study showed that only structural capital has a significant and positive relationship with profitability measures. Further, the findings showed that the banking sector was the most relaxed on the Intellectual Capital, followed by companies in the brokerage and insurance industry. Finally, the findings indicated that intellectual capital has a positive relationship with firm performance.

In a study by Hwan (2014) on human intellectual capital, it was concluded that the economic value of an organization's productivity is dependent more on employee intellectual skills and knowledge, and business problem solving ability as compared to its market value of the firm's commercial output. Accordingly, while past economies were dependent on use of natural resources (land, equipment and capital for the creation of value), present economies rely on intellectual capital and the application of knowledge. This implies that knowledge is a very important resource for people, firms and countries. The study concluded that management of knowledge and intellectual capital creates new source of competitive advantage, thus, the fortunes and values of firms can increase or decrease depending on how well they capture, create and leverage their knowledge.

In Kenya, Mumia (2014) studied the relationship between intellectual capital and financial performance of companies listed in the Nairobi Securities Exchange. A total of 239 observations were deduced from panel data for the period 2009 to 2013. Regression and correlation analyses were used to test the strength and direction of Intellectual capital and other variables that influence organization performance. Intellectual capital was measured by Tobin's q ratio of Market value to tangible assets while performance was measured by Return on Equity (ROE). The findings indicated that intellectual capital had a negative and non-significant effect on ROE. The study concluded that intellectual capital does not influence financial performance of listed firms in the Nairobi Securities Exchange and recommended that the firms should focus on other parameters to improve their performance other than intellectual capital.

In a study by Cerrato and Piva (2014) on internationalization of SMEs, the effect of three constructs were explored; family management, intellectual capital and foreign ownership. The study adopted survey research design and the sample comprised of data from 1,324 Italian manufacturing SMEs. The findings established that involvement of the family owners in management of enterprises has negative influence on the export propensity of the SME especially where internationalization has been adopted. Results further revealed that the geographical scope of the SME and the choice of internationalization have some significance when compared with the behaviour of non-family managed enterprises. Findings also established that the extent of intellectual capital and the presence of foreign financiers and shareholders in the SME have positive significant influence on the prospects of internationalization of the firm. The study recommended that propensity for innovation, age and relatively size of the firm and its inherent industrial characteristics may act as control variables in this study.

In another study, Al-Musali and Ismail (2014) examined the interaction between corporate governance, bank specific characteristics, and bank industry characteristics, and the level of intellectual capital performance among listed commercial banks in Arab Gulf Cooperation Council (GCC). To analyze the Value added intellectual coefficient (VAIC) methodology, longitudinal survey was applied in order to realize the hypothesized relationship between the variables, such as bank specific characteristics and banking industry characteristics on intellectual capital performance. The findings revealed that the size of the board, the population of independent directors, propensity to family ownership, and domestic strategic institutional ownership have positive and significant relationship with intellectual capital performance of banks. Additionally, the findings revealed that bank specific and banking industry characteristics have significant contribution for performance of intellectual capital among banks in GCC countries.

A study was conducted by Visnu and Gupta (2014) on the intellectual capital and performance of pharmaceutical companies in India. The study also aimed at conceptualizing, proposing, and testing modified models of Value Added Intellectual Coefficient (VAIC) method on the relationship between the intellectual capital and performance of pharmaceutical companies. Intellectual capital was analyzed using its three components, namely; human capital, relational capital, and structural capital, while performance of pharmaceuticals companies was measured through Return on Assets (ROA) and Return on Sales (ROS). Descriptive cross-section survey was used to collect data from 22 large pharmaceutical firms in India. The findings established that there is existence of a positive and significant relationship between intellectual capital and the performance of performance of pharmaceuticals companies as measured through ROA and ROS. The study concluded that intellectual capital has significant effect on performance of pharmaceutical industry in India. 


\section{Research and methodology}

The study applied positivism philosophical approach and descriptive cross-sectional research design. The target population constituted top and middle level managers in forty commercial banks in Kenya. Using Yamane's formula, a sample size of 400 respondents was selected through multi-stage sampling. Data was collected using a structured questionnaire and analyzed using SPSS version 23.0 in terms of factor analysis and structural equation modeling to establish the relationships between managerial intellectual capital and internationalization. Analysis of Moment Structures (AMOS) was also undertaken to construct the model linking the managerial intellectual capital and internationalization.

\section{Results}

\section{Exploratory factor analysis}

Exploratory Factor Analyses (EFA) was conducted through Kaiser Meyer-Olin (KMO) Measure of Sampling Adequacy and Bartlett's Test of Sphericity was used to assess factorability of items. Managerial intellectual capital was identified by three variables, namely; structural capital, human capital and relational capital. The validity inspection of this measurement model indicated that the level of model fit was satisfied as shown in Table 1.

Table 1: KMO and Bartlett's test for intellectual capital

\begin{tabular}{lll}
\hline \multicolumn{2}{l}{ Kaiser-Meyer-Olkin Measure of Sampling Adequacy. } & $\mathbf{. 8 8 0}$ \\
\hline Bartlett's Test of Sphericity & Approx. Chi-Square & 2050.795 \\
\hline & Df & 78 \\
\hline & Sig. & .00 \\
\hline
\end{tabular}

Results in Table 1 indicates that the coefficient of Keiser-Meyer Olkin (KMO) measure of sampling adequacy was 0.880 since it was greater than 0.5 as recommended by Cerny and Kaiser (1977). This indicated that the data was adequate to allow for factor analysis. The Bartlett's test of sphericity was significant $(\chi 2(78, \mathrm{~N}=283)=2050.795, p=0.00)$, an indication that patterns of correlations are close and factor analysis should yield consistent and reliable factors.

\section{Confirmatory factor analysis for intellectual capital}

Confirmatory factor analysis (CFA) was conducted in order to assess the extent to which the observed data fits the pre-specified theoretically driven model. The results are summarized in Figure 1.

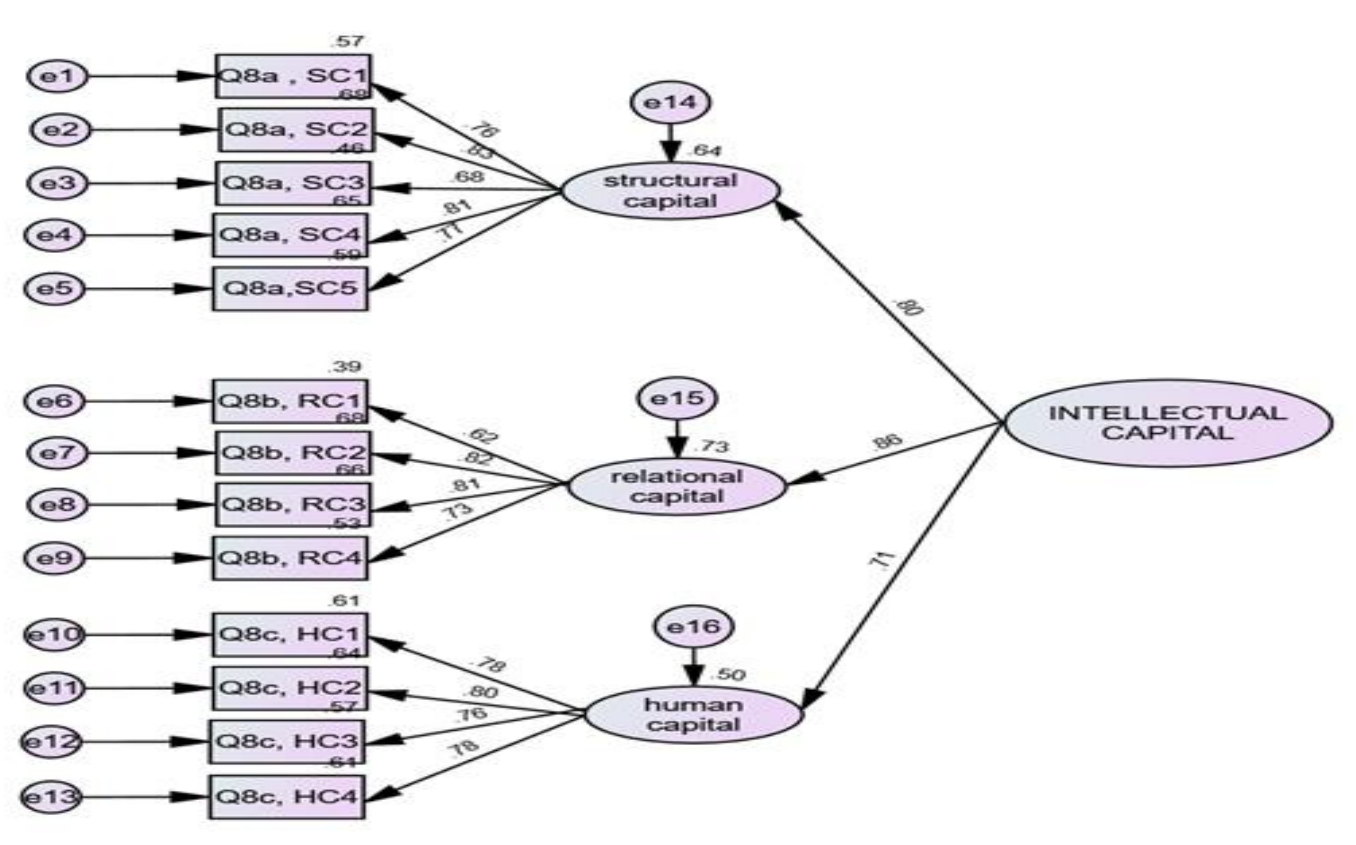

$\chi^{2}=251.413 ; \chi 2 / \mathrm{df}=3.928 ; \mathrm{DF}=64 ; \mathrm{CFI}=0.907 ; \mathrm{GFI}=0.910 ; \mathrm{RMSEA}=0.04$

Fig. 1: Confirmatory factor analysis for intellectual capital 
Results show the Chi-square value was 251.413 with 64 degrees of freedom. The p-value associated with this result was significant at $\mathrm{p}=0.00$. In addition to the Chi-square results, the comparative fit index (CFI) that analyzes the model fit by examining the discrepancy between the data and the hypothesized model, while adjusting for the issues of sample size inherent in the chi-squared test of model fit and the normed fit index, was estimated. CFI values range from 0 to 1 , with larger values indicating better fit (Hair et al., 2010). The value for CFI was 0.907, which is above the 0.90 threshold advised by Hair et al. (2010) hence acceptable, while the values for absolute fit indices were 0.910 for goodness-of-fit (GFI), which is above the required 0.90 threshold, hence acceptable (Bagozzi \& Yi, 1988).

GFI range between 0 and 1, with a value of over 9 generally indicating an acceptable model fit. RMSEA, which avoids issues of sample size by analyzing the discrepancy between the hypothesized model, with optimally chosen parameter estimates, and the population covariance matrix should range from 0 to 1 , with smaller values indicating better model fit. A value of .08 or less is indicative of acceptable model fit (Hair et al., 2010). This study's RMSEA was 0.04, and indication that it was a good fit. These results suggest that the measurement model for intellectual capital provided a reasonably good fit as summarized in figure 1 .

\section{Correlations for intellectual capital}

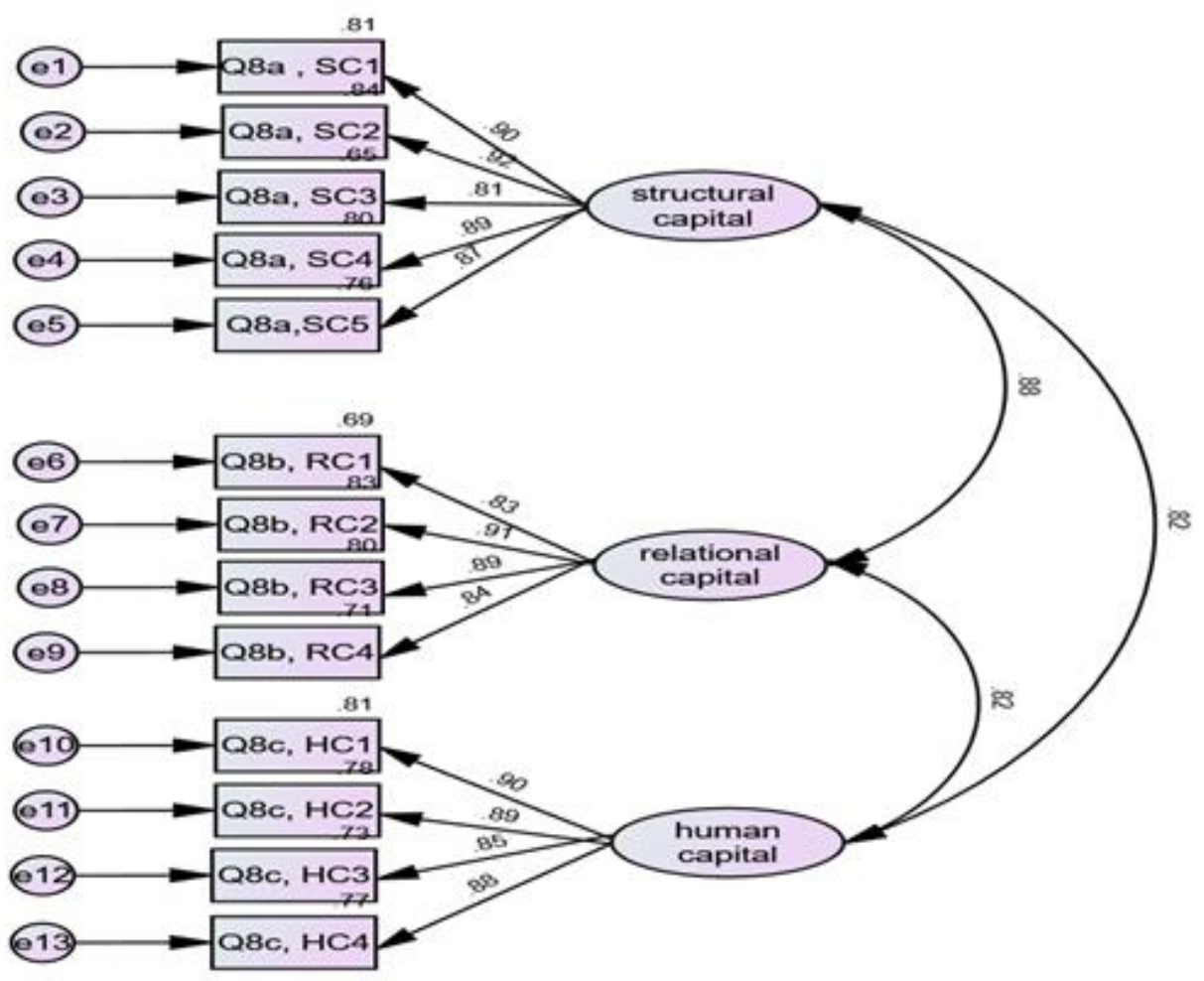

$\chi 2370.819 ; \chi 2 / \mathrm{df}=5.705 ; \mathrm{DF}=65 ; \mathrm{CFI}=0.907 ; \mathrm{GFI}=0.910 ; \mathrm{RMSEA}=0.04$

Fig. 2: Correlations for intellectual capital

Results indicate that the factor loading estimates were significant and ideal at $\mathrm{p}=0.00$. An examination of inter-correlations between the three dimensions of value of 0.907 , implying distinctness in construct content or discriminant validity. The congeneric measurement model, with all uni-dimensional constructs, did not contain any cross-loadings, either among the measured variables or among the error terms. Taken together, these results supported the measurement model validity, thus, confirming that intellectual capital is a second-order latent construct composed of structural capital, relational capital and human capital.

\section{Structural equation model for intellectual capital and Internationalization}

Using the methodology of Structural Equation Modeling (SEM) technique is similar to standard approaches like correlation, multiple regressions and ANOVA only that it is a more powerful, complex and analytical technique. It includes; the modeling of interactions, nonlinearities, correlated independent measurement error, correlated error terms, multiple latent independents with each measured by multiple indicators, and one or more latent dependents with each having multiple indicators. This was guided by the null hypothesis that, managerial intellectual capital has no significant influence on internationalization of commercial banks in Kenya. The R-squared value, path coefficients and model fit results for the influence of intellectual capital on internationalization are shown in Figure 2. 


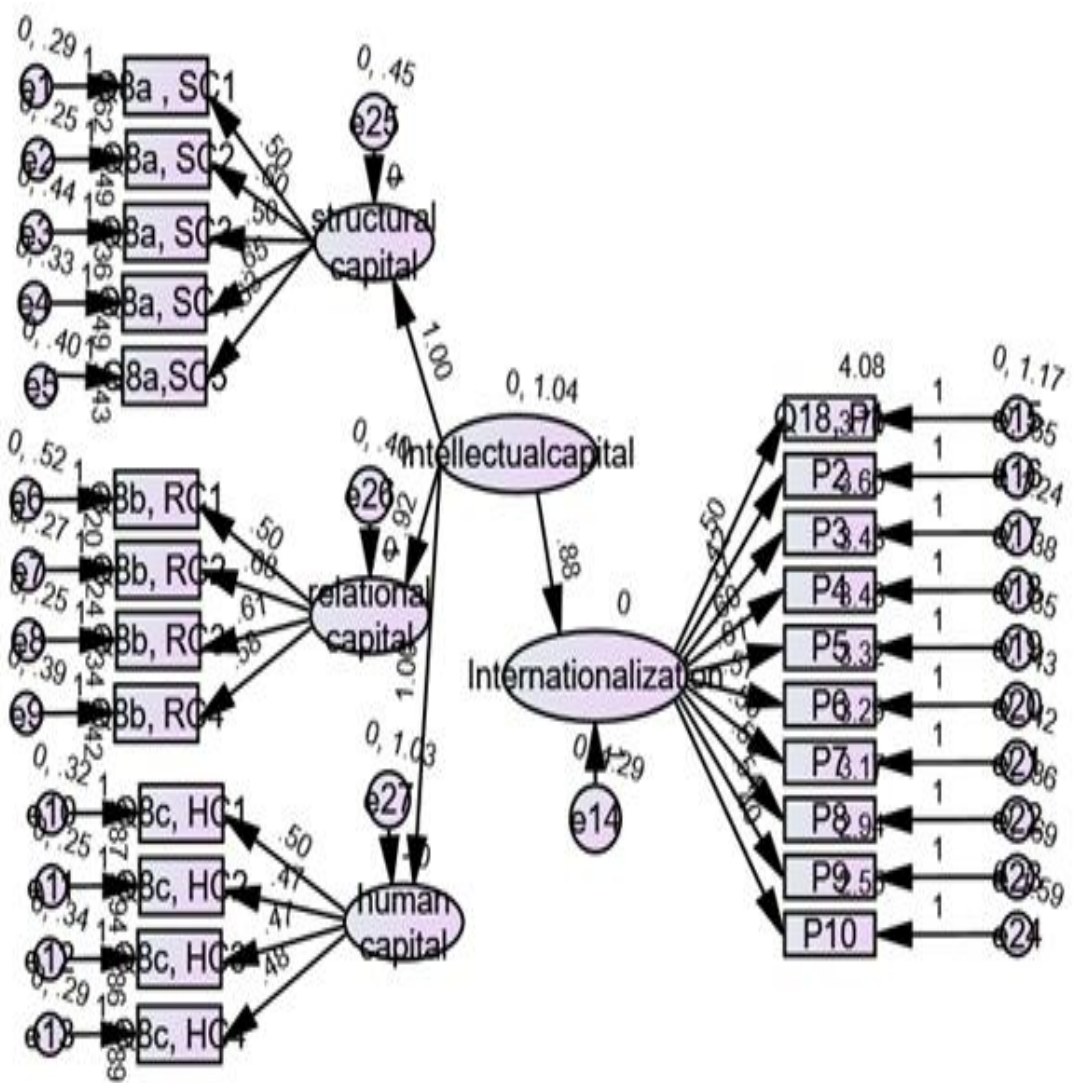

Fig. 3: SEM model for intellectual capital

Based on the estimated structural equation model, for every magnitude change in intellectual capital, internationalization increases by 0.88 units. In this model, the R-square was significant with a value of 20 percent. This implies that intellectual capital has a significant positive influence on internationalization and explained 20 percent of the variance in internationalization $\left(R_{2}=0.20\right)$ by commercial banks in Kenya. This R2 value exceeds Falk and Miller's (1992) recommendation that R2 as an indicator of substantive explanatory power should be greater than or equal to 10 per cent.

\section{Path coefficients for intellectual capital}

To determine the relationship between intellectual capital and internationalization, a test was performed for the Path coefficient. Table 2 below shows the results.

Table 2: Path coefficients for intellectual capital

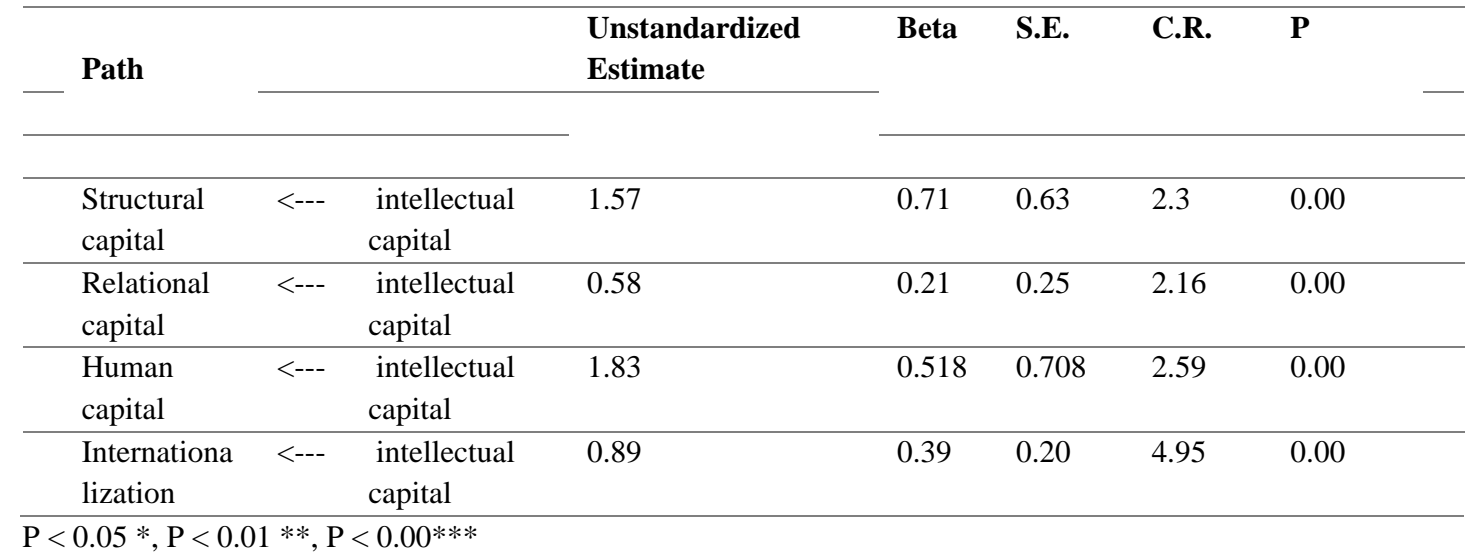

The relationship between intellectual capital and internationalization was positive and statistically significant $(\beta \mathrm{eta}=0.39, \mathrm{~T}=4.95$, $\mathrm{P}<0.05)$. Therefore, the study rejects the null hypothesis and accepts the alternative hypothesis and concludes that intellectual capital has significant influence on internationalization of commercial banks in Kenya.

\section{Model fits for intellectual capital}

The Model Fits for intellectual capital is indicated as shown below. 
Table 3: Model fits for intellectual capital

\begin{tabular}{llll}
\hline Measure & Result & Threshold & Interpretation \\
\hline GFI & 0.90 & $>0.90$ & Acceptable \\
\hline CFI & 0.94 & $>0.90$ & Acceptable \\
\hline RMSEA & 0.04 & $<0.08$ & Acceptable \\
\hline
\end{tabular}

Results indicates that the value for CFI, an incremental fit index, was 0.94, which is above the 0.90 threshold (Hair et al, 2010), hence acceptable. The values for absolute fit indices were 0.90 for goodness-of-fit (GFI), which is equal to the required 0.90 threshold (Bagozzi \& Yi, 1988), hence acceptable. Lastly, the value for RMSEA was 0.04, which was below the 0.08 threshold hence excellent fit (Hair et al., 2010). These results suggest that the measurement model for intellectual capital provided a reasonably good fit.

\section{Discussions}

The findings show that intellectual capital positively influences internationalization of commercial banks in Kenya. This led to the rejection of the null hypothesis. This meant that managerial intellectual capital has significant influence on internationalization of commercial banks in Kenya. Despite the fact that the intellectual capital considered was limited to human capital, relational capital and structural capital, it was evident that the three factors have significant influence on the success of the internationalization strategy. This is in support of previous studies done by Melendez (2017), and Crema and Verbano (2016).

A study by Hwan (2014) assessed the relationship between managers' business ethics and the development of intellectual capital. Similar to results of the current study, results from Hwan's (2014) study showed that intellectual capital had significant impact on organizational performance. Accordingly, the economic value of an organization's productivity is dependent more upon employee intellectual skills and knowledge, and business problem solving ability as compared to its market value of the firm's commercial output. The intellectual capital among managers influences the decisions they make, choices they consider, and perspectives they adopt when implementing strategies.

Findings from Mumia's (2014) study contradicts the current study where by it was observed that there exists a negative relationship between intellectual capital and financial performance of companies listed in the Nairobi Securities Exchange. The findings further indicate that intellectual capital could equally not have any influence on internationalization as a measure of performance. The contradiction between the current study and findings could be attributed to the fact the study was limited to financial performance, while the current study focused on internationalization. This implies that relating managerial intellectual capital and financial performance has the possibility of creating limitations that may not be generalized on other areas like internationalization.

The current study findings are also supported by Singh et al. (2016) in acknowledgement that there exists a mutually positive correlation between innovative activities and intellectual capital. Also, Singh et al. found that the amassing of intellectual capital of banks has positive influences on their development and expansion. Similarly, the current study findings support the findings by Ariff et al. (2016) in a study that explored intellectual capital and market performance in the case of multinational R\&D firms in the United States. The findings revealed a positive correlation between intellectual capital and the companies' expected performance. Equally, the current study findings support Abd et al. (2014) who studied intellectual capital amongst commercial banks and found that intellectual capital contributes more to innovation and organizational performance compared to structural and relational capital. However, findings contrasted with Morris (2014) who noted that structural capital and relational capital are both attributes of intellectual capital. This is in line with the findings of the current study, which found that relational capital, structural capital, and human capital are all constructs of intellectual capital.

Current study findings are also in support of a study by Sui and Baum (2014) on the relationship between the internationalization of commercial banks and intellectual capital, which revealed that certain dimensions of intellectual capital may be more associated to commercial banks' internationalization than others. The study findings further support Oparaocha (2015) who highlighted that the born-global view is associated with human capital and, secondary, with relational capital; while the Uppsala model advances more the structural capital and, subsidiary, human capital. On the other hand, Pacheco (2016) complements the study findings that within the resource-based view, human capital is central, followed by structural capital, and then relational capital.

In this case, the intellectual capital covers skills, capabilities and acquired knowledge that comprise of a set of attributes that assist the achievement of sustainable international. The findings are consistent with Yeoh (2014), who also found that intellectual capital should be viewed as a wealth creator with an immense potential to produce competitive advantage and sustainability in global banking. Findings by Doornich (2018) conclude by supporting that intellectual capital had a positive impact on commercial banks' sustainable growth, and in the process extending the potential of intellectual capital in creating value and building sustainable advantages in emerging economies. Similarly, Visnu and Gupta (2014) had also established that there is existence of positive and significant relationship between intellectual capital and the performance of organizations. 


\section{Conclusions}

This research concludes that intellectual capital has a positive and significant influence on internationalization of commercial banks in Kenya. This means that structural capital, relational capital and human capital are inherent of managers' ability to influence the success internationalization strategies by commercial banks. As an attribute of global mindset, intellectual capital is a critical factor that can influence how internationalization strategies are implemented. More particularly, the study concludes that the three intellectual capital attributes, namely structural capital, human capital and relational global capital, individually and jointly influence the success of internationalization by commercial banks in Kenya.

It is recommended that management of banks, while going international, need to consider factors such as an individual's knowledge of global industry, knowledge of global value networks and knowledge of the global organization in their strategic planning and appointment of the team responsible for foreign market expansion.

This study offers practitioners in strategic management, policy makers, and the managerial of commercial banks suggestions on how to improve in their implementation of internationalization strategies. More particularly, decision makers within the bank may find the recommendations significant while appointing the team responsible for the internationalization process. On further research, to establish to what extent is global mindset beneficial to banks that have ventured into international markets?

\section{References}

Abd, Z., Hassan, H., \& Ahmad, I. (2014). Intellectual capital amongst commercial banks. Handbook on Emerging Trends in Scientific Research, 1(1),399-409.

Al-Musalli, M. A. K., \& Ismail, K. N. I. K. (2014). Corporate governance, bank specific characteristics, banking industry characteristics, and intellectual capital (IC) performance of banks in Arab Gulf Cooperation Council (GCC) countries. Asian Academy of Management Journal of Accounting \& Finance, 8(1).

Ariff, A., Islam, A., \& Van Zijil, T. (2016). Intellectual capital and market performance: The case of multinational R\&D firms in the U.S. Journal of Developing Area, 50(5), 487-490. http://doi.org/10.1353/jda.2016.0052

Asira, A. (2013). Internationalization of indigenous Kenya commercial banks within Eastern Africa: A survey of selected commercial banks (Unpublished thesis). The University of Nairobi, Nairobi, Kenya

Bagozzi, R. \& Yi, Y. (1988). The evaluation of structural equation models. Journal of the Academy of Marketing Sciences, 1(6), 7494. https://doi.org/10.1007/BF02723327

Bartlet, C. \& Beamish, P. (2014). Transnational management: Text cases and reading in cross border management. Singapore:

Boddewyn, J., Halbrich, M., \& Perry, A. (1986). Service multinationals: conceptualization, measurement and theory. Journal of International Business Studies, 17(3), 41-57. https://doi.org/10.1057/palgrave.jibs.8490860

Cerny, C., \& Kaiser, H. (1977). A study of a measure of sampling adequacy for factor analytic correlation matrices. Multivariate Behavioral Research, 12(1), 43-47. https://doi.org/10.1207/s15327906mbr1201_3

Cerrato, D., \& Piva, M. (2014). The internationalization of small and medium-sized enterprises: The effect of family management, intellectual capital and foreign ownership. Journal of Management \& Governance, 16(4), 617-644. https://doi.org/10.1007/s10997-010-9166-x

Langley, A., Small Man, H., \& Tsoukas, A. (2015). Process studies of change in organization and management. Journal of Academy of Management, 7(3), 1-13. https://doi.org/10.5465/amj.52.5.zoj1069

Levene, R. A. (2015). Positive psychology at work: Psychological capital and thriving as pathways to employee engagement. Journal of Management and International Review, 1(2), 5-7.

Chebii, C. (2015). Analysis of internationalization of banking in emerging markets in Kenya. Nairobi: University of Nairobi Press.

Conrad, H., \& Meyer, H. (2018). Brokers and the organization of recruitment of global talent. Social Science Japan, 13(2), 21-32. https://doi.org/10.1093/ssjj/jyx032

Crema, M., \& Verbano, C. (2016). Managing intellectual capital in Italian manufacturing SMEs. Creativity and Innovation Management, 3(2), 400-408. https://doi.org/10.1111/caim.12074

Crowne, K. A. (2013). Cultural exposure, emotional intelligence and cultural intelligence: An exploratory study. International Journal of Cross Cultural Management, 1(2), 637. https://doi.org/10.1177\%2F1470595812452633

Doornich, J. B. (2018). Managerial learning from social capital during internationalization. International Business Review, $27,877-$ 892. https://doi.org/10.1016/j.ibusrev.2018.01.010

Fatehi, K., \& Ghadar, F. (2014). A Measure of international managers' mindset. International Journal of Commerce and Management, 2(1), 321-333. https://doi.org/10.1108/IJCoMA-01-2012-0006

Falk, R. \& Miller, Nancy. (1992). A Primer for Soft Modeling. The University of Akron Press: Akron, OH

Gacoki, R. (2014). Challenges of internationalization of banking operations by Kenya Commercial Bank Limited (Unpublished maters' thesis). The, University of Nairobi, Nairobi, Kenya.

Vahlne, J. E., \& Johanson, J. (2017). From internationalization to evolution: The Uppsala model at 40 years. Journal of International Business Studies, 48(9), 1087-1102. https://doi.org/10.1057/s41267-017-0107-7

Gota, G. (2017). The relationship between psychological capital, work engagement and organizational commitment amongst employees at a selected food processing plant in the Western Cape. Western Cape: University of Western Cape. 
Hair Jr., J. F., Black, W. C., Babin, B. J., \& Anderson, R. E. (2010). Multivariate aata analysis. Upper Saddle River: Prentice Hall.

House, R. (2013). The global mindset of managers: What it is, why it matters and how to develop it. Organizational Dynamics, 1(2), $145-155$.

Hugo, S. (2016). Challenges faced by SMEs in the internationalization process to emerging markets and ways to overcome them. Catolica Lisbon, 22(3), 23-45.

Hwan, Y. (2014). Business ethics and the development of intellectual capital. Journal of Business Ethics, 4(4), 87-98. https://doi.org/10.1007/s10551-013-1623-4

Islam, M. S., Khan, A. M., Nasreen, S., Rabbi , F., \& Islam, R. (2011). Renewable energy: The key to achieving sustainable development of rural Bangladesh. Dhaka: Unpublished.

Jie, M. (2014). Globalization of Chinese commercial banks (Unpublished masters thesis). Mary's University.

Maike, A., \& Franziska, B. (2017). A systematic literature review on the definitions of global mindset and cultural intelligence: Merging two different research streams. The International Journal of Human Resource Management, 2(8), 10-17. https://doi.org/10.1080/09585192.2016.1243568

Marthinsen, E. (2015). Exploring the relationship between global mindset and performance during foreign market entry. Copenhagen Business School, 13(2), 144-178.

elendez, J. A., Wesolowski, S., \& Furnstahl, R. J. (2017). Bayesian truncation errors in chiral effective field theory: nucleon-nucleon observables. Physical Review C, 96(2), 024003. https://doi.org/10.1103/PhysRevC.96.024003

Mona, R. C. (2017). Relation between global mindset and internationalization of companies: A case of BILA A/SMS. International Business Economics, 3(3), 76.

Mori, Y. (2015). New collectivism. World Art, 167-170.

Morris, C. (2014). An empirical investigation of the impact of human capital on the financial and market performance of South African Listed Companies (Doctoral dissertation, Stellenbosch: Stellenbosch University).

Mumia, J. (2014). The relationship between intellectual capital and financial performance of companies listed in the Nairobi Securities Exchange. (Unpublished thesis, University of Nairobi, Kenya).

Marta, C. P. (2015). Uppsala model VS Born global theory. Catholic University of Portugal, Lisbon Portugal.

Massingham, P. (2013). Cognitive complexity in global mindset. International Journal of Management, 1(1), 232-248.

Nadeem, M. (2016). Intellectual capital and firm performance: Evidence from developed, emerging and frontier markets of the world. Research Archive, 3(3), 150-167. https://hdl.handle.net/10182/7745

Oparaocha, O. (2015). SMEs and international entrepreneurship: An institutional network perspective. International Business Review, 24(5 ), 861-873. https://doi.org/10.1016/j.ibusrev.2015.03.007

Otor, E. (2015). The influence of intellectual capital on the performance of small and medium enterprises: A case of Mombasa count, Kenya (Masters thesis). Nairobi: University of Nairobi.

Pacheco, L. (2016). Capital structure and internationalization: The case of Portuguese industrial SMEs. Research International and Business Finance, 3(8), 531-545. https://doi.org/10.1016/j.ribaf.2016.07.014

Poh, L., Kilicman, A., \& Ibrahim, S. (2018). On intellectual capital and financial performances of banks in Malaysia. Cogent Economics and Finance, 22(2), 34-56. https://doi.org/10.1080/23322039.2018.1453574

Singh, S., Sidhu, J., \& Joshi, M. (2016). Measuring intellectual capital performance of Indian banks: A public and private sector comparison. Managerial Finance, 16(30), 635-655. https://doi.org/10.1108/MF-08-2014-0211

Story, J. S., Barbuto, J. E., Luthans, F., \& Bavarid, J. A. (2014). Meeting the challenges of effective international HRM: Analysis of the antecedents of global mindset. Human Resource Management, 12(4), 131-155. https://doi.org/10.1002/hrm.21568

Sui, S., \& Baum, M. (2014). Internationalization strategy, firm resources and the survival of SMEs in the export market. Journal of International Business Studies. 4(5), 821-841. https://doi.org/10.1057/jibs.2014.11

Terrell, S., \& Rosenbusch, K. (2013). Global leadership development: What global organizations can do to reduce leadership risk, increase speed to competence, and build global leadership muscle? People \& Strategy, 36(1), 40.

Thi, H. (2014). Initiating the international process of Vietnamese born global firms. (Unpublished thesis) University of Vaasa, Finland.

Vătămănescu, E., Elena-Alexandra, G., Alexandru, M. G., \& Pătruț, M. (2019). Internationalization through the lens of sustainable competitive advantage: A systematic literature review. The International Journal of Intellectual Capital, 1(2), 6-7. https://doi.org/10.3390/su11092510

Vishnu, S., \& Gupta, K. V. (2014). Intellectual capital and performance of pharmaceutical firms in India. Journal of Intellectual Capital, 15(1), 83-99. https://doi.org/10.1108/JIC-04-2013-0049

Yamada, K. (2016). Financing sustainable development with enhanced domestic resource mobilization. Asia-Pacific Development Journal, 2(2), 61-80.

Yeoh, P. (2014). Internationalization and performance outcomes of entrepreneurial family SMEs: The role of outside CEOs, technology sourcing, and innovation. Thunderbird International Business Review, 56(1), 77-96. (3), 193-207. https://doi.org/10.1002/tie.21597 